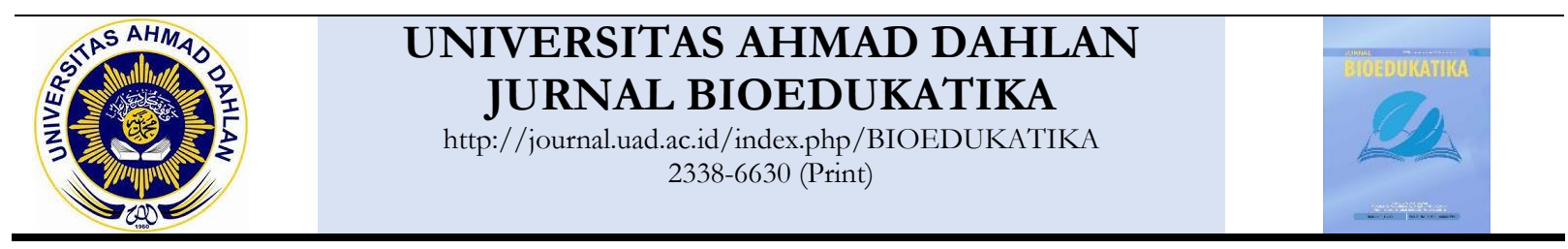

\title{
Analisis komponen penyusun desain kegiatan laboratorium bioteknologi
}

\author{
Iseu Laelasari a, 1, *, Bambang Supriatno ${ }^{\text {b, } 2}$ \\ ${ }^{a}$ Pendidikan IPA IAIN Kudus, J1 Conge Ngembalrejo Kotak Pos 51 Bae Kudus 59322, Indonesia \\ ${ }^{\mathrm{b}}$ Pendidikan Biologi Universitas Pendidikan Indonesia, J1 Dr Setiabudhi No 229 Bandung 40154, Indonesia \\ ${ }^{1}$ iseulaelasari@stainkudus.ac.id; ${ }^{2}$ bambangs@upi.edu \\ *korespondensi penulis
}

\begin{tabular}{ll}
\hline Informasi artikel & \\
\hline Sejarah artikel: & \\
Diterima & 17 Juli 2018 \\
Revisi & 1 November 2018 \\
Dipublikasikan & 15 Desember 2018 \\
\hline
\end{tabular}

Kata kunci:

Desain kegiatan laboratorium

Tujuan praktikum

Proses kegiatan laboratorium

Pertanyaan praktikum

Bioteknologi \begin{abstract}
ABSTRAK
Tujuan dalam penelitian ini untuk mendeskripsikan tiga komponen utama dalam desain kegiatan laboratorium bioteknologi yakni tujuan, proses dan pertanyaan yang dapat digunakan sebagai dasar untuk melakukan rekonstruksi terhadap desain kegiatan laboratorium tersebut. Pengambilan sampel dilakukan secara purposif dengan mengambil 10 sampel desain kegiatan laboratorium yang terdapat di sepuluh SMA Negeri di kota Bandung. Peneliti mengembangkan instrument berupa tabel deskriptif yang digunakan untuk menganalisis keterkaitan antara komponen tujuan, proses dan pertanyaan. Hasil menunjukkan bahwa praktikum secara keseluruhan mengarah pada kategori meningkatkan pemahaman terhadap materi pelajaran dan mengembangkan keterampilan dasar. Hanya 20\% tujuan praktikum mengacu pada indikator hasil penjabaran Kompetensi Dasar, tergambar dalam langkah kerja dan dapat dicapai setelah melakukan kegiatan laboratorium, $20 \%$ proses sesuai dengan tujuan, berstruktur logis, sistematis, serta tepat dalam menghasilkan data, dan temuan mengungkap hanya 39,28\% pertanyaan yang bersesuaian dengan tujuan dan proses. Sisanya bermasalah terutama dalam hal tidak tergambarnya tujuan dalam langkah kerja, tidak dapat dicapainya tujuan, proses tidak mengacu pada tujuan, tidak logis, dan juga tidak sistematis, tidak menghasilkan data yang diharapkan, serta tidak mengacunya pertanyaan pada tujuan ataupun proses. Hasil tersebut merupakan temuan yang dapat dijadikan sebagai dasar untuk melakukan rekonstruski terhadap desain kegiatan laboratorium bioteknologi.
\end{abstract}

Key word:

Lab Activity Design

Lab Objectives

Lab Activity Process

Lab Questions

Biotechnology

\begin{abstract}
Analysis of bjectives process and questions as a basic for reconstruction lab activities design of biotechnology. The aims of this study was to describe the components of objectives, processes, and questions in Biotechnology lab activities design that can used as a basis for reconstruction it. Sample was taken purposively by taking 10 samples of lab activities design in 10 SMA Negeri in Bandung. Researchers developed descriptive table as instrument that used to analyze the interrelations between objective, process and questions. The results show that overall lab objectives leads to category of developing basic skills and improving understanding of subject matter. There are only $20 \%$ of objectives which refer to Basic Competence outcome indicator, illustrated in activity step, and can be achieved after lab activities, $20 \%$ of process refers to objectives, systematic and logical structure, and can produce correct data, and only $39,28 \%$ of questions refer to objectives and processes. The rest is problematic especially in event that objectives are not illustrated in activity steps, objectives can not be achieved, process is not referring to objectives, not systematic and illogical, and does not produce expected data, question does not refer to objectives or process. These results are findings can be used as a basic for reconstruction lab activities design of biotechnology.
\end{abstract}

Copyright (C) 2018 Universitas Ahmad Dahlan 


\section{Pendahuluan}

Kegiatan laboratorium dapat digunakan sebagai alternatif kegiatan untuk mengeksplor dan memaksimalkan potensi belajar siswa melalui kegiatan bioscience pertama, yakni siswa dapat mengembangkan diri dalam pembelajaran biologi sebagai bagian dari sains, melalui kegiatan berbasis laboratorium (Croker, Andersson, Lush, Prince, \& Gomez, 2010). Pembelajaran berbasis kegiatan laboratorium memiliki potensi untuk (1) mengajarkan keterampilan manipulasi, (2) memahami penggunaan peralatan, (3) membantu pemahaman inquiri ilmiah (meliputi merancang eksperimen, melaksanakan eksperimen, mengumpulkan data, interpretasi data), (4) mengembangkan sikap terhadap sains, (5) memberikan pengenalan berupa contoh-contoh nyata terhadap konsep-konsep abstrak (Lagowski, 2002). Kegiatan laboratorium dapat memberikan kesempatan pada siswa untuk menguji kebenaran teori dalam keadaan yang nyata dan dapat di indera (Tapilouw \& Saefudin, 2008).

Teori maupun konsep dalam sains dapat dibuktikan secara efektif melalui kegiatan laboratorium. Selain itu melalui kegiatan laboratorium guru dapat mengemas pembelajaran menjadi lebih menarik untuk dilakukan oleh siswa (Newton, 2006). Pembelajaran laboratorium juga potensial untuk mengembangkan kemampuan ranah kognitif dan afektif siswa dalam pembelajaran sains (Lee, Lai, Alex Yu, \& Lin, 2012). Dalam rangka mengoptimalkan potensi kegiatan laboratorium tersebut, maka kegiatan praktikum ini perlu dilakukan secara berkesinambungan, karena ketika kegiatan ini dilakukan dalam jangka pendek, hal tersebut kurang mengembangkan motivasi siswa pasca pelaksanaan kegiatan untuk mengeksplorasi pengetahuan mereka tentang sains (Abrahams, 2009).

Sebagai upaya untuk melaksanakan kegiatan laboratorium secara berkesinambungan, maka dalam pembelajaran sains, dapat dilakukan dengan mengintegrasikan kegiatan laboratorium tersebut dalam proses pembelajaran. Hal tersebut juga dapat mengarahkan proses aktif siswa selama proses pembelajaran, melatih kemampuan inquiri, mengumpulkan data dan fakta, sistematis dalam mendeskripsikan objek, membuktikan teori dan prinsip, mengajukan pertanyaan, melakukan discovery, dan mengomunikasikan hasil temuan. Menurut Supriatno (2009) kegiatan laboratorium dapat memberikan kesan yang utuh dan lebih bermakna kepada siswa, karena selama pembelajaran mereka cenderung melibatkan berbagai indera seperti penglihatan, penciuman, pendengaran, peraba dan pengecapan.

Kegiatan laboratorium yang dilakukan oleh siswa umumnya mengacu pada suatu Desain Kegiatan Laboratorium (DKL). Desain kegiatan ini yang berisi sejumlah langkah kerja operasional dapat memandu praktikan dalam melaksanakan kegiatan di laboratorium. DKL dapat diwujudkan ke dalam bentuk LKS maupun terintegrasi ke dalam buku paket. Menurut Rustaman \& Wulan (2007) LKS (Lembar Kerja Siswa) merupakan salah satu media pembelajaran yang berisi petunjuk untuk melaksanakan kegiatan laboratorium. Suatu LKS yang baik hendaknya mencakup beberapa aspek, yaitu (1) tujuan kegiatan, (2) pendahuluan (berupa dasar teori) (3) alat dan bahan, (4) prosedur kerja, (5) cara perangkaian alat, (6) interpretasi data hasil pengamatan, (7) analisis data dan (8) simpulan (A. Rustaman \& Wulan, 2007).

Berkaitan dengan aspek-aspek tersebut, Supriatno (2007) mengkaji 46 sampel LKS Biologi, yang hasilnya mengungkap bahwa sebagian besar pembuat LKS tidak atau belum melakukan uji coba LKS tersebut dari segi proses ataupun produk yang dihasilkan. Temuan mengungkap banyaknya langkah kerja yang kurang terstruktur dan tidak mengarahkan untuk memperoleh data yang benar. Selain itu, hasil uji keterlaksanaan prosedur kerja (Supriatno, 2009) menunjukkan bahwa, langkah kerja yang dapat dikerjakan dan menghasilkan data yang benar, tuntas dalam analisis serta dapat digunakan untuk membuat simpulan hanya berkisar $24 \%$. Sisanya sebanyak $76 \%$ bermasalah dalam: (1) tidak terstrukturnya langkah kerja, (2) kesulitan dalam eksekusi langkah kerja (3) kekakuan tabel data dan menimbulkan hasil yang miskonsepsi, (4) membutuhkan waktu yang lama, dan (5) ketidaktuntasan.

Salah satu diantara konsep Biologi yang potensial untuk dikembangkan melalui kegiatan praktikum adalah Bioteknologi. Konsep tersebut bersesuaian dengan Standar Kompetensi Lulusan (SKL) yakni siswa diharapkan untuk bisa memahami prinsip dasar bioteknologi serta implikasinya pada salingtemas (Kemendikbud, 2014). Terdapat beberapa pertimbangan mengapa praktikum bioteknologi perlu dikembangkan, yakni (1) variasi kegiatan praktikum bioteknologi masih kurang, (2) memerlukan waktu yang cukup lama, (3) keterkaitan urutan materi dalam kurikulum, yakni bioteknologi merupakan bab terakhir yang dipelajari di kelas XII sehingga pelaksanaan kegiatan laboratorium kecil kemungkinan untuk dilakukan, padahal melalui kegiatan laboratorium banyak mengembangkan potensi materi bioteknologi. 
Kajian mengenai komponen tujuan, proses, dan pertanyaan desain kegiatan laboratorium pada konsep bioteknologi sebagai studi pendahuluan ini menjadi penting karena akan berhubungan dengan kualitas suatu proses yang akan menentukan output pembelajaran. Kajian ini dapat memberikan gambaran mengenai komponen tujuan, proses, dan pertanyaan dalam desain kegiatan laboratorium, dan dapat digunakan sebagai rujukan dalam melakukan modifikasi dan rekonstruksi dalam rangka memperbaiki kualitas suatu proses kegiatan laboratorium menggunakan desain kegiatan laboratorium konsep bioteknologi.

\section{Metode}

Penelitian ini dilakukan dengan cara menganalisis sejumlah DKL SMA kelas XII konsep bioteknologi yang terdapat di dalam buku paket biologi, LKS internal (dibuat sendiri oleh guru), dan LKS yang diterbitkan. Sampel diambil secara purposif dengan mengambil sampel desain kegiatan laboratorium yang terdapat di 10 SMA Negeri di kota Bandung, dengan dasar pertimbangan bahwa sekolah tersebut pernah melaksanakan kegiatan praktikum bioteknologi. 10 sampel tersebut terdiri dari 8 desain kegiatan laboratorium yang terdapat di dalam buku paket, 1 LKS internal dan 1 LKS yang diterbitkan. Penelitian ini menggunakan tiga instrumen yang telah dikembangkan oleh peneliti dan telah divalidasi oleh ahli, berupa lembar deskriptif yang berisi tabel analisis untuk menjaring data mengenai tiga komponen utama dalam desain kegiatan laboratorium, yakni tujuan, proses (langkah kerja), dan komponen pertanyaan.

Berdasarkan hasil validasi instrumen, komponen tujuan dianalisis mengenai aspek mengacu tidaknya tujuan praktikum terhadap indikator, ketergambaran tujuan dalam langkah kegiatan, ketercapaian tujuan, serta kategori tujuan praktikum menurut Woolnough (dalam N. Rustaman et al., 2003). Komponen Proses kegiatan laboratorium dianalisis dari aspek mengacu tidaknya proses terhadap tujuan, kesistematisan dan kelogisan struktur langkah kerja dan perolehan data. Sedangkan komponen pertanyaan dianalisis dari aspek mengacu tidaknya pertanyaan terhadap proses beserta tujuan yang dikembangkan.

Dalam rangka mengurangi bias dari hasil analisis data mengenai komponen tujuan, proses, dan pertanyaan yang terdapat dalam DKL, dilakukan triangulasi data antar peneliti dan triangulasi teori. Triangulasi antar peneliti dilakukan dengan cara membandingkan hasil analisis data untuk setiap komponen yang telah diperoleh oleh peneliti pertama dengan pandangan dan argumentasi peneliti kedua yang merupakan ahli dalam bidang praktikum dan penyusunan desain kegiatan laboratorium biologi. Sedangkan untuk triangulasi teori dilakukan dengan membandingkan setiap hasil analisis data dengan perspektif teori yang relevan. Misalnya dalam menganalisis kelogisan dan kesistematisan struktur langkah kerja, peneliti membandingkan konsep eksplisit dalam setiap langkah tersebut dengan kesesuaian konsep dalam kajian bioteknologi.

\section{Hasil dan pembahasan}

Data hasil analisis kategori tujuan praktikum mengacu pada kategori menurut Woolnough disajikan pada Tabel 1.

Tabel I. Analisis kategori tujuan praktikum menurut Woolnough dalam desain kegiatan laboratorium konsep bioteknologi

\begin{tabular}{|c|c|c|c|}
\hline \multirow[t]{2}{*}{ DKL } & \multicolumn{3}{|c|}{ Kategori Tujuan Praktikum } \\
\hline & $\begin{array}{c}\text { Mengemba } \\
\text { ngkan } \\
\text { keterampil } \\
\text { an dasar }\end{array}$ & $\begin{array}{l}\text { Mengembangka } \\
\text { n kemampuan } \\
\text { memecahkan } \\
\text { masalah }\end{array}$ & $\begin{array}{c}\text { Meningkatkan } \\
\text { pemahaman } \\
\text { terhadap } \\
\text { materi } \\
\text { pelajaran }\end{array}$ \\
\hline 1 & $\sqrt{ }$ & - & $\sqrt{ }$ \\
\hline 2 & $\sqrt{ }$ & - & $\sqrt{ }$ \\
\hline 3 & $\sqrt{ }$ & - & $\sqrt{ }$ \\
\hline 4 & $\sqrt{ }$ & - & $\sqrt{ }$ \\
\hline 5 & $\sqrt{ }$ & - & $\sqrt{ }$ \\
\hline 6 & $\sqrt{ }$ & $\sqrt{ }$ & $\sqrt{ }$ \\
\hline 7 & - & - & - \\
\hline 8 & $\sqrt{ }$ & - & $\sqrt{ }$ \\
\hline 9 & $\sqrt{ }$ & - & $\sqrt{ }$ \\
\hline 10 & $\sqrt{ }$ & - & $\sqrt{ }$ \\
\hline
\end{tabular}

DKL : Desain Kegiatan Laboratorium

Berdasarkan Tabel 1, komponen tujuan praktikum secara keseluruhan dapat mengarah pada kategori meningkatkan pemahaman terhadap materi pelajaran dan mengembangkan keterampilan dasar, dan hanya 10\% tujuan praktikum berada pada kategori tujuan untuk mengembangkan kemampuan memecahkan masalah. Hal tersebut dikarenakan bentuk praktikum yang dilakukan dengan mengacu pada desain kegiatan laboratorium yang dianalisis pada dasarnya berbentuk latihan dan memberi pengalaman. Hal ini sesuai dengan penjelasan yang dikemukakan oleh Woolnough (dalam N. Rustaman et al., 2003) bahwa bentuk praktikum latihan digunakan untuk mengembangkan keterampilan dasar, bentuk praktikum investigasi digunakan untuk melatih kemampuan dalam pemecahan masalah, dan bentuk praktikum yang bersifat memberi pengalaman digunakan untuk membantu memahami materi pelajaran. 
Hasil tersebut menunjukkan bahwa model desain kegiatan laboratorium konsep bioteknologi yang beredar saat ini kurang variatif, cenderung mengarah pada model verifikasi. Hal ini sesuai dengan hasil penelitian Supriatno (2007) bahwa $78,3 \%$ LKS dari jenjang SMP dan SMA merupakan model ekspositori (verifikasi). Kegiatan praktikum dengan model tersebut dapat membantu siswa untuk memahami objek fisik yang mereka inginkan, namun kurang mengeksplorasi ide-ide ilmiah siswa untuk membimbing kegiatan dan mengolah data yang telah dikumpulkan (Abrahams \& Millar, 2008).

Hal ini berbeda dengan pendapat Lagowski (2002) terdapat empat model instruksional laboratorium yaitu exspository (verifikasi), inquiry, discovery, problem-based. Diantara ke empat model tersebut, model inquiry lebih mengarahkan kegiatan autentik berdasarkan pengalaman nyata, sehingga siswa dapat memposisikan sebagai seorang saintis (Longo, 2011). Setiap model tersebut memiliki kelebihan dan kekurangannya, sehingga dibutuhkan kombinasi penggunaan desain kegiatan laboratorium untuk mengembangkan potensi siswa yang diharapkan. Bersesuaian dengan hasil temuan Basey, Maines, Francis, \& Melbourne (2014), bahwa diperlukan kombinasi antara dua tipe model hands on pembelajaran laboratorium untuk bisa mengembangkan High Order Thinking Skills dan Low Order Thinking Skill. Adanya keragaman bentuk praktikum menurut Lagowski (2002) diperlukan untuk mencegah situasi monoton dan membosankan pada suatu jenjang pendidikan.

Tujuan praktikum juga dianalisis dengan membandingkan kesesuaian tujuan dengan indikator, ketergambaran tujuan dalam langkah kerja, dan ketercapaian tujuan setelah melakukan kegiatan labiratorium, yang hasilnya disajikan pada Tabel 2.

Tabel 2. Analisis tujuan dalam desain kegiatan laboratorium bioteknologi

\begin{tabular}{ccc}
\hline Hasil Analisis Tujuan & $\begin{array}{c}\text { Jumlah } \\
\text { DKL }\end{array}$ & $\begin{array}{c}\text { Persentase } \\
\text { (\%) }\end{array}$ \\
\hline $\begin{array}{c}\text { Tujuan mengacu pada indikator, } \\
\text { tidak tergambar dalam langkah, } \\
\text { dan tidak dapat dicapai }\end{array}$ & 6 & $60 \%$ \\
$\begin{array}{c}\text { Tujuan mengacu pada indikator, } \\
\text { tergambar dalam langkah tetapi } \\
\text { tidak dapat dicapai }\end{array}$ & 1 & $10 \%$ \\
$\begin{array}{c}\text { Tujuan mengacu pada indikator, } \\
\text { tergambar dalam langkah, dan } \\
\text { dapat dicapai }\end{array}$ & 2 & $20 \%$ \\
$\begin{array}{c}\text { Tidak mencantumkan tujuan } \\
\text { Total DKL/ Total \% }\end{array}$ & 1 & $10 \%$ \\
\hline
\end{tabular}

Berdasarkan Tabel 2 hanya 20\% tujuan praktikum mengacu pada indikator hasil penjabaran Kompetensi Dasar, tergambar dalam langkah kerja dan dapat dicapai setelah melakukan kegiatan laboratorium, $70 \%$ bermasalah dalam hal tidak tergambarnya tujuan dalam langkah kerja dan tidak tercapainya tujuan, dan terdapat $10 \%$ DKL yang tidak mencantumkan tujuan praktikum. Hasil ini sesuai dengan penjelasan yang dikemukakan oleh Supriatno (2009) bahwa keberhasilan dari suatu praktikum tergantung pada langkah-langkah yang dikerjakan siswa dalam rangka mencapai tujuan yang telah ditentukan sebelumnya. Dengan demikian maka suatu tujuan praktikum harus dibuat saling berkesinambungan dengan langkah kerja supaya dapat tercapai. Hal tersebut penting karena berhubungan dengan produk pembelajaran berupa pengetahuan yang akan diperoleh siswa. Menurut Dahar (2011) pengetahuan yang dapat diperoleh siswa melalui suatu pembelajaran/ praktikum bergantung pada dua aspek yang saling berkaitan satu sama lain, yaitu siswa harus mengetahui tujuan dari kegiatan yang akan dilakukan, dan sampai seberapa jauh tujuan tersebut dapat dicapai oleh siswa.

Selain data hasil analisis tujuan, diperoleh juga data hasil analisis langkah kerja yang menggambarkan proses kegiatan laboratorium, yang disajikan dalam Tabel 3.

Tabel 3. Persentase analisis langkah kerja (Proses) dalam desain kegiatan laboratorium bioteknologi

\begin{tabular}{ccc}
\hline Hasil Analisis Proses & $\begin{array}{c}\text { Jumlah } \\
\text { DKL }\end{array}$ & $\begin{array}{c}\text { Persentase } \\
\text { (\%) }\end{array}$ \\
\hline $\begin{array}{c}\text { Proses tidak mengacu pada } \\
\text { tujuan, tidak sistematis, } \\
\text { tidak logis, dan tidak }\end{array}$ & 4 & $40 \%$ \\
menghasilkan data yang \\
diharapkan
\end{tabular}

Dikaji dari aspek proses sebagaimana yang disajikan pada Tabel 3, dapat diketahui bahwa 20\% proses kegiatan laboratorium yang dilakukan mengacu pada tujuan, memili struktur yang logis dan sistematis, serta dapat menghasilkan data yang diharapkan, sisanya sebanyak $70 \%$ menunjukkan langkah kerja tidak sistematis, tidak logis, dan juga 
tidak dapat memperoleh data yang tepat, $10 \%$ dari DKL yang dianalisis tidak mencantumkan tujuan. Hasil tersebut sesuai dengan apa yang dijelaskan Supriatno (2009) bahwa apabila siswa mengerjakan langkah kerja yang tidak terstruktur ataupun ambigu (membingungkan) maka dapat mengakibatkan kegagalan dalam proses laboratorium yang dilakukan. Kegagalan ini dikarenakan tidak diperolehnya data yang diharapkan untuk membantu siswa dalam menyimpulkan. Apabila prosedur kegiatan salah, maka pada dasarnya siswa belajar pengetahuan yang salah dan hal ini dapat memicu timbulnya miskonsepsi bagi siswa.

Salah satu contoh yang membuktikan hal tersebut adalah langkah kerja yang tercantum dalam dua desain kegiatan laboratorium mengenai perbanyakan tanaman melalui metode kultur jaringan. Langkah tersebut sangat menyimpang dari konsep mengenai kultur jaringan. Proses yang dilakukan tidak mencerminkan prinsip mikropropagasi melalui kultur jaringan, sehingga apabila guru tidak mengaji/merekonstruksi langkah kerja sebelum digunakan sebagai petunjuk praktikum, dapat menimbulkan miskonsepsi mengenai konsep kultur jaringan. Sangat disayangkan apabila kegiatan laboratorium bioteknologi yang pada umumnya memerlukan waktu lama untuk mengerjakannya, menghasilkan produk pengetahuan yang tidak sebanding/ pengetahuan yang salah dikarenakan adanya kesalahan langkah kerja.

Menurut Millar (2004) keefektifan/ efektivitas suatu kerja praktikum dapat diukur dari segi (1) prosedur kegiatan, yakni berkaitan dengan apa yang dikerjakan siswa, dan (2) hasil kerja praktikum, dalam hal ini berkaitan dengan apa yang dipelajari siswa Efektivitas langkah kerja yang dimaksud merupakan terlaksananya langkah/ prosedur kerja dalam desain kegiatan laboratorium dan juga dapat menghasilkan data/fakta yang diharapkan. Menurut Supriatno (2009) adanya langkah kerja yang salah dalam suatu LKS dapat mengakibatkan tingkat efektivitas kerja menjadi berkurang. Apabila efektivitas kerja berkurang, maka pada dasarnya siswa banyak mengerjakan yang tidak seharusnya dikerjakan. Dengan demikian siswa belajar tidak mengenai apa yang seharusnya dipelajari.

Dikaji dari aspek pertanyaan sebagaimana disajikan pada Tabel 4, terdapat 39,28\% pertanyaan yang mengacu pada tujuan maupun proses, $14,29 \%$ tidak mengacu pada tujuan maupun proses, sisanya sebanyak $46,43 \%$ hanya mengacu pada salah satu aspek (tujuan saja atau proses saja). Hasil tersebut menunjukkan bahwa pertanyaan yang ada dalam desain kegiatan laboratorium bioteknologi kurang merujuk pada proses praktikum yang dilakukan dan pencapaian tujuan. Padahal menurut N. Rustaman et al., (2003) suatu pertanyaan harus dibuat sesuai dengan tujuan dan dapat mengukur tingkat keberhasilan belajar. Tingkat keberhasilan belajar yang dimaksud dalam kegiatan laboratorium diperoleh melalui proses kegiatan laboratorium yang dilakukan mengikuti langkah kerja.

Tabel 4. Analisis pertanyaan dalam desain kegiatan laboratorium bioteknologi

\begin{tabular}{ccc}
\hline Hasil Analisis Pertanyaan & Jumlah & $\begin{array}{c}\text { Persentase } \\
(\%)\end{array}$ \\
\hline $\begin{array}{c}\text { Pertanyaan mengacu pada } \\
\text { tujuan dan proses }\end{array}$ & 11 & $39,28 \%$ \\
$\begin{array}{c}\text { Pertanyaan mengacu pada } \\
\text { tujuan tetapi tidak mengacu } \\
\text { pada proses }\end{array}$ & 4 & $14,29 \%$ \\
$\begin{array}{c}\text { Pertanyaan tidak mengacu } \\
\text { pada tujuan dan proses }\end{array}$ & 4 & $14,29 \%$ \\
$\begin{array}{c}\text { Pertanyaan tidak mengacu } \\
\text { pada tujuan tetapi mengacu } \\
\text { pada proses }\end{array}$ & 9 & $32,14 \%$ \\
$\begin{array}{c}\text { Total Pertanyaan/Total } \\
\text { Persentase }\end{array}$ & 28 & $100 \%$ \\
\hline${ }^{2}$ DKL : Desain Kegiatan Laboratorium &
\end{tabular}

Senada dengan pendapat Hasibuan \& Moedjiono (2008) bahwa suatu pertanyaan pada dasarnya ditujukan untuk: (1) membantu siswa belajar, (2) menstimulasi siswa dalam mengembangkan kemampuan berpikir (3) memandu interaksi belajar dan kemandirian (4) meningkatkan kemampuan higher order thinking skill, dan (5) membantu pencapaian ujuan pelajaran. Dengan demikian maka pertanyaan yang disajikan dalam suatu desain kegiatan laboratorium hendaknya mengarah pada pencapaian tujuan dan mengukur ketercapain hasil dari proses laboratorium yang dilakukan.

Pertanyaan yang mengacu pada tujuan berarti pertanyaan tersebut dapat mengarahkan pada pencapaian konsep yang tercantum dalam tujuan, sementara pertanyaan yang mengacu pada proses berarti bahwa pertanyaan tersebut mengarahkan pada langkah kerja dan data yang dihasilkan. Hasil analisis terhadap sejumlah pertanyaan yang tercantum dalam desain kegiatan laboratorium bioteknologi, terdapat beberapa pertanyaan yang bersifat konseptual yang dapat dijawab siswa tanpa menggunakan data yang diperoleh, maupun bersifat prosedural yang menanyakan tentang bagaimana mengerjakan sesuatu yang dapat dijawab apabila praktikan mengerjakan sejumlah prosedur/langkah tertentu. Ditemukan juga beberapa pertanyaan yang 
menanyakan alasan mengenai dilakukannya suatu langkah, sementara dalam desain kegiatan laboratoriumnya tidak ada perintah untuk melaksanakan langkah tersebut. Selain itu terdapat juga pertanyaan yang sama sekali tidak berhubungan dengan tujuan dan proses yang dilakukan.

Pertanyaan yang mengacu pada tujuan dan proses, pada umumnya berupa pertanyaan yang mengarahkan pada pembuatan simpulan dari percobaan dan pertanyaan-pertanyaan lain yang mengarahkan pada pencapaian konsep yang tercantum dalam tujuan, serta sesuai dengan langkah yang dilakukan. Misalnya, pada desain kegiatan praktikum dengan tujuan "membuat tape singkong" terdapat pertanyaan "apakah fungsi penambahan ragi pada percobaan tersebut?". Pertanyaan tersebut mengacu pada tujuan dan proses karena ragi merupakan bahan penting yang digunakan dalam pembuatan tape, dan juga terdapat data yang diperoleh dari hasil percobaan untuk menjawab pertanyaan tersebut.

Pertanyaan yang mengacu tujuan namun tidak mengacu proses, pada umumnya merupakan pertanyaan konseptual yang dapat diarahkan untuk mencapai tujuan, tetapi tetapi tidak diperoleh data dari proses yang dilakukan untuk untuk menjawab pertanyaan tersebut. Misalnya, pada desain kegiatan laboratorium dengan tujuan "mengekstraksi DNA dari Kacang Kapri”, terdapat pertanyaan "jelaskan bagaimana bentuk DNA yang kamu peroleh?". Pertanyaan tersebut mengacu pada tujuan karena menanyakan tentang konsep DNA, tetapi tidak mengacu pada proses karena tidak ada data yang diperoleh dari langkah kerja yang dapat digunakan untuk menjawab pertanyaan mengenai bentuk DNA.

Adapun pertanyaan yang tidak merujuk pada tujuan namun mengacu proses, pada umumnya merupakan pertanyaan yang mengarahkan pada data yang diperoleh dari langkah kerja, tetapi karena langkah tersebut tidak mengacu pada tujuan/menyimpang dari tujuan maka pertanyaan tersebut dikategorikan sebagai pertanyaan yang tidak mengacu pada tujuan yang tercantum. Misalnya pada desain kegiatan laboratorium dengan tujuan "mengembangkan tanaman dengan teknik kultur jaringan", terdapat pertanyaan "di antara wadah nomor 1-3 tersebut, bagian tanaman manakah yang paling baik tumbuh, mengapa? Berapa lama waktu yang digunakan?”. Pertanyaan tersebut mengacu pada proses yang dilakukan, karena terdapat data yang diperoleh dari langkah kerja untuk menjawab pertanyaan tersebut, tetapi karena langkah kerja yang dilakukan menyimpang dari konsep kultur jaringan (sebagaimana dicantumkan dalam tujuan praktikum), maka pertanyaan tersebut tidak mengacu pada tujuan.

Pertanyaan yang tidak mengacu pada tujuan dan proses, pada umumnya merupakan pertanyaan yang sama sekali tidak berhubungan dengan langkah kerja, serta tidak dapat mengarahkan pada pencapaian tujuan yang diharapkan. Misalnya pada desain kegiatan laboratorium dengan tujuan praktikum "mengetahui proses fermentasi tempe sebagai produk bioteknologi konvensional", terdapat pertanyaan "apa sajakah kandungan gizi yang terdapat di dalam tempe?". pertanyaan tersebut tidak mengacu pada tujuan dan proses karena konsep utama yang tercantum dalam tujuan praktikum adalah proses fermentasi tempe, bukan kandungan gizi tempe, sehingga tidak ada data yang diperoleh untuk menjawab pertanyaan tersebut.

Hasil analisis tersebut menegaskan bahwa komponen pertanyaan yang ada dalam desain kegiatan laboratorium harus bersesuaian dengan proses yang dilakukan dan tujuan yang ingin dicapai, sehingga siswa dapat menjawab pertanyaan yang tercantum melalui data yang telah mereka kumpulkan. Hal ini sesuai dengan penjelasan A. Rustaman \& Wulan (2007) bahwa pertanyaan yang ada hendaknya dapat menuntun siswa pada pokok persoalan, dan dapat dijawab oleh siswa. Dalam hal ini pertanyaan dapat digunakan untuk mengukur ketercapaian proses dan tujuan, menuntun praktikan untuk memahami konsep yang dipelajari dan mengarahkan praktikan untuk membuat suatu kesimpulan yang tepat.

\section{Simpulan}

Berdasarkan hasil analisis 10 desain kegiatan laboratorium bioteknologi mengenai komponen tujuan, proses, dan pertanyaan, dapat disimpulkan bahwa secara keseluruhan tujuan praktikum mengarah pada kategori tujuan untuk mengembangkan keterampilan dasar dan meningkatkan pemahaman terhadap materi pelajaran. Hanya 20\% tujuan praktikum mengacu pada indikator hasil penjabaran Kompetensi Dasar, tergambar dalam langkah kerja dan dapat dicapai setelah melakukan kegiatan laboratorium, 20\% proses sesuai dengan tujuan, berstruktur logis, sistematis, serta tepat dalam menghasilkan data, dan temuan mengungkap hanya 39,28\% pertanyaan yang bersesuaian dengan tujuan dan proses. Sisanya sebanyak $80 \%$ bermasalah dalam hal tidak tergambarnya tujuan dalam langkah kerja dan tidak dapat dicapainya tujuan praktikum, $80 \%$ proses tidak mengacu pada tujuan, tidak logis, struktur langkah kerjanya tidak sistematis, serta tidak dapat menghasilkan data yang diharapkan, dan 60,72\% 
pertanyaan tidak mengacu pada tujuan ataupun proses. Hasil tersebut merupakan temuan yang dapat dijadikan sebagai dasar untuk melakukan modifikasi dan rekonstruksi terhadap desain kegiatan laboratorium bioteknologi.

\section{Referensi}

Abrahams, I. (2009). Does practical work really motivate? A study of the affective value of practical work in secondary school science. International Journal of Science Education, 31(17), 2335-2353. https://doi.org/ $10.1080 / 09500690802342836$

Abrahams, I., \& Millar, R. (2008). Does practical work really work? A study of the effectiveness of practical work as a teaching and learning method in school science. International Journal of Science Education, 30(14), 1945-1969. https://doi.org/10.1080/095006907017493 05

Basey, J. M., Maines, A. P., Francis, C. D., \& Melbourne, B. (2014). An evaluation of two hands-on lab styles for plant biodiversity in undergraduate biology. CBE_Life Sciences Education, 13(3), 493-503. https://doi.org/10.1187/ cbe.14-03-0062

Croker, K., Andersson, H., Lush, D., Prince, R., \& Gomez, S. (2010). Enhancing the student experience of laboratory practicals through digital video guides. Bioscience Education, 16(1), 1-13. https://doi.org/10.3108/ beej. 16.2

Dahar, R. W. (2011). Teori-teori belajar. Jakarta: Erlangga.

Hasibuan, J. J., \& Moedjiono. (2008). Proses belajar mengajar: Bandung: Remaja Rosdakarya.

Kemendikbud. (2014). Konsep dan implementasi kurikulum 2013. Jakarta. Diambil dari https://www.kemdikbud.go.id/kemdikbud/d okumen/Paparan/Paparan Wamendik.pdf

Lagowski, J. J. (2002). The role of the laboratory in chemical education. Austin, Texas. Diambil dari http://citeseerx.ist.psu.edu/viewdoc/ download?doi $=10 \cdot 1 \cdot 1 \cdot 567.5825 \& \mathrm{rep}={ }_{\text {rep }} 18$ ty $\mathrm{pe}=\mathrm{pdf}$

Lee, S. W.-Y., Lai, Y.-C., Alex Yu, H.-T., \& Lin, Y.-T. K. (2012). Impact of biology laboratory courses on students' science performance and views about laboratory courses in general: innovative measurements and analyses. Journal of Biological Education, 46(3), 173-179. https://doi.org/10.1080/00219266.2011.63 4017

Longo, C. M. (2011). Designing inquiry-oriented science lab activities. Middle School Journal, 43(1), 6-
15. 00940771.2011 .11461788

https://doi.org/10.1080/

Millar, R. (2004). The role of practical work in the teaching and learning of science. Washington. Diambil dari http://sites. nationalacademies.org/cs/groups/dbassesite/d ocuments/webpage/dbasse_073330.pdf

Newton, S. (2006). International practical science guide: Advice and activities for primary and secondary science in the classtoom. The Association for Science Education and University of Cambridge International Examinations. Google Books

Rustaman, A., \& Wulan, A. R. (2007). Kegiatan laboratorium dalam pembelajaran biologi. Jakarta: Universitas Terbuka. Google Scholar

Rustaman, N., Dirdjosoemarto, S., Yudianto, S. A., Achmad, Y., Subhekti, R., Rochintaniawati, D., \& Nurjhani, M. (2003). Strategi belajar mengajar biologi. Malang: UM Press. Google Scholar

Supriatno, B. (2007). Profil lembar kegiatan biologi siswa sekolah menengah. dalam Proseding Seminar Nasional Jurusan Pendidikan Biologi. Bandung: Universitas Pendidikan Indonesia.

Supriatno, B. (2009). Uji langkah kerja laboratorium biologi sekolah. dalam Proseding Seminat Nasional Jurusan Pendidikan Biologi. Bandung: Universitas Pendidikan Indonesia.

Tapilouw, F. S., \& Saefudin. (2008). Pembelajaran berbasis laboratorium untuk meningkatkan penguasaan konsep dan sikap ilmiah siswa tentang sistem pencernaan makanan. Jurnal Penelitian Pendidikan IPA, 11(3), 301-308. 